\title{
Invasion of Hawaiian shores by an Atlantic barnacle
}

\author{
A. J. Southward ${ }^{1, *}$, R. S. Burton ${ }^{2}$, S. L. Coles ${ }^{3}$, P. R. Dando ${ }^{4}$, R. DeFelice ${ }^{3}$, J. Hoover ${ }^{5}$, \\ P. E. Parnell ${ }^{6}$, T. Yamaguchi ${ }^{7}$, W. A. Newman ${ }^{2}$ \\ ${ }^{1}$ Department of Biology, University of Victoria, Victoria, British Columbia V8W 2Y2, Canada \\ ${ }^{2}$ Scripps Institution of Oceanography, University of California San Diego, La Jolla, California 92093-0202, USA \\ ${ }^{3}$ Department of Natural Sciences, B. P. Bishop Museum, Honolulu, Hawaii 96817, USA \\ ${ }^{4}$ School of Ocean Science, University of Wales Bangor, Menai Bridge, Anglesey LL59 5EY, United Kingdom \\ ${ }^{5}$ Hawaii Medical Library, 1221 Punchbowl Street, Honolulu, Hawaii 96813, USA \\ ${ }^{6}$ Oceanography Department, University of Hawaii, 1000 Pope Road, Honolulu, Hawaii 96822, USA \\ ${ }^{7}$ Department of Earth Sciences, Chiba University, Yoyoi-cho, Inage, Chiba 263, Japan
}

\begin{abstract}
A largely vacant niche in the upper mid-littoral zone of sheltered Hawaiian shores is now occupied by Chthamalus proteus Dando \& Southward, 1980 (Crustacea, Cirripedia), otherwise found in the Caribbean, the Gulf of Mexico and Brazil. The identity of the species was established by morphological details and confirmed by allozyme electrophoresis. Previously, chthamaline barnacles have rarely been found fouling hulls of ships; this is the first recorded instance of regular occurrence on ships as well as of remote dispersal in the genus. While the introduction of C. proteus apparently has had little impact so far, there is a need to step up monitoring programs so as to prevent rather than simply detect future introductions.
\end{abstract}

KEY WORDS: Chthamalus proteus - Remote dispersal - Introduced species · Fouling - Enzyme electrophoresis - Setal characters

\section{INTRODUCTION}

The terrestrial fauna and flora of islands is depauperate to a degree that is proportional to distance from continental sources (MacArthur \& Wilson 1967), and this applies also to the marine environment. The Hawaiian islands in the mid-Pacific are notably isolated (Ekman 1953, Zimmerman 1963), and their marine fauna lacks many taxa that are abundant elsewhere in the tropics, leaving vacant niches.

Hawailan cirripeds are low in species diversity. Pilsbry (1928) reported only 13 taxa, of which 4 were of worldwide occurrence on floating objects, and 4 were new. Newman (1986) added 5 lepadomorphs, 3 balanomorphs and 3 acrothoracicans, but compared to continental shores this number was still small. A general survey of the shore barnacles of Oahu (Matsuda 1973) included 3 comparatively recent introductions. These are the com-

\footnotetext{
- Address for correspondence: Marine Biological Association, Citadel Hill, Plymouth PL1 2PB, United Kingdom

E-mail: 100721.3720@compuserve.com
}

mon fouling barnacles Balanus amphitrite, Darwin, 1854, Balanus reticulatus Utinomi, 1967, and Balanus eburneus Gould, 1841 that are often found together in sheltered habitats. The first was described by Broch (1922) as B. a. hawaiiensis from Pearl Harbor, and is now regarded as $B$. amphitrite of world-wide distribution (Utinomi 1960, Harding 1962). B. reticulatus, sometimes confused with B. amphitrite (Utinomi 1967. Henry \& McLaughlin 1975, Southward 1975), was also introduced to Hawaii, where it was detected in samples from the Ala Wai Canal in 1956 (W.A.N. pers. obs.). B. eburneus was tentatively listed by Edmonson (1946), who reported it from 2 localities, Ala Wai Canal, Oahu, and Maalea Bay Harbor, Maui. Its identity was confirmed by Matsui et al. (1964), and its distribution on Oahu given by Matsuda (1973).

The surveys by Edmonson (1946) and Matsuda (1973) confirmed that the islands were then without any representative of the common intertidal genus Chthamalus (as revised by Newman \& Ross 1976). Chthamalus has a world-wide distribution in most tropical and temperate latitudes, but in the central 
Pacific it had previously been observed only as far east as Ponape and Truk, and then in embayments (Newman 1960, W.A.N. pers. obs.). The coastal intertidal zone of the central Pacific islands, including Hawaii, is inhabited by a chthamaloid barnacle, Nesochthamalus intertextus (Darwin, 1854), of a much older lineage than Chthamalus. Fig. 1 illustrates the differences in shell morphology between the genera.

We were therefore very surprised that in 1996 a species of Chthamalus (Figs. 1 \& 2) was found to be abundant at several localities on Oahu; it was photographed and collected in Kaneohe Bay (by J.H. while preparing
A

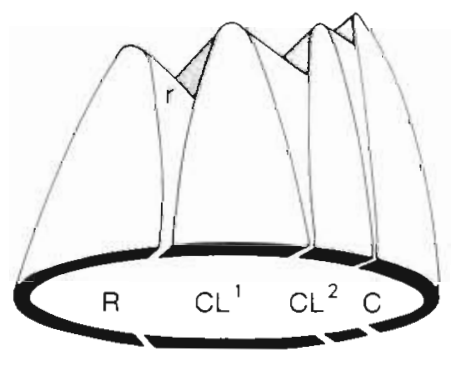

BALANID

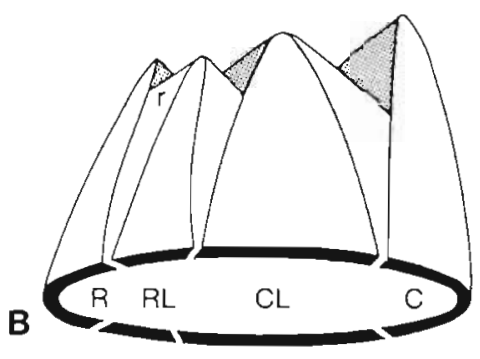

CHTHAMALID

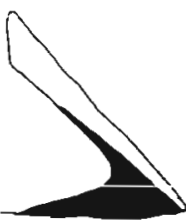

Nesochthamalus intertextus

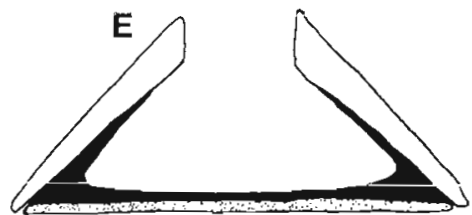

Euraphia hembeli
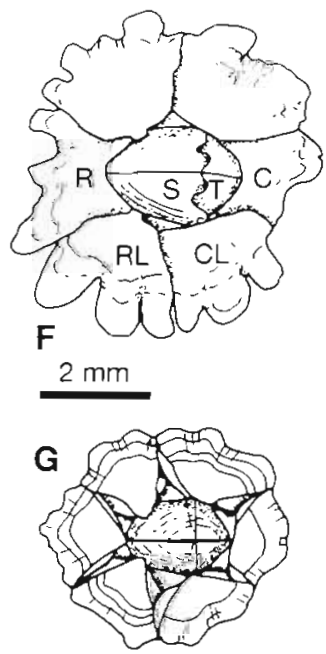

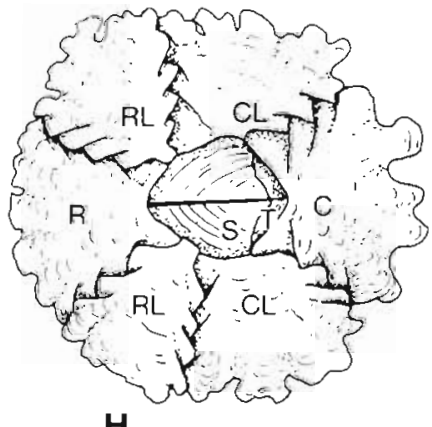

H

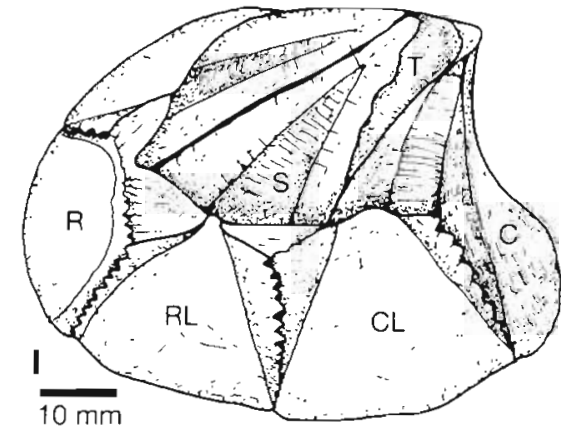

$2 \mathrm{~mm}$

Fig. 1. How to distinguish chthamalids from balanids, and how to separate the intertidal chthamalids of Hawail. (A, B) Comparison of balanid and chthamalid walls (viewed from right side). (A) In the balanid wall, the rostrum (R) has radii [r, structures overlapping the alae (stippled) of the adjacent plates known as the carinolaterals ( $\mathrm{CL}^{1}$, the carinolateralis, formerly the medianlateralis, and $\mathrm{CL}^{2}$, the second carinolatus, formerly the carinolateralis)]. (B) In the chthamalid wall, the rostrum (R) has alae [stippled, structures overlapped by the radii of the adjacent plates (RL, the rostrolateral)]. C: carina; CL: carinolateral (or carinolateralis). Note that the rostrum is generally simple in chthamalids and compound in balanids. (C-E) Sagittal sections of the walls of mature specimens of the 3 intertidal chthamalids presently known from the Hawaiian Islands, Chthamalus proteus, Nesochthamalus intertextus, and Euraphia hembeli, respectively, revealing the lack of longitudinal tubes in parietal parts (white) in all three, (C) a membranous basis (dashed) in C. proteus, (D) a membranous basis (dashed) plus partial secondary calcification of the wall and basis (black) in $N$. intertextus, and ( $\mathrm{E}$ ) a true calcareous basis (stippled) plus complete secondary calcification (black) of the wall and basis in $E$. hembeli. ( $F, G)$ Mature and juvenile $C$. proteus, respectively; note the relatively simple, untoothed sutures between wall plates in both, and exposure of a sinusoidal suture between the scutum and tergum ( $\mathrm{S}$ and $\mathrm{T}$ ) of each side due to corrosion in the mature specimen. $(\mathrm{H}, \mathrm{I})$ Mature but uneroded $N$. intertextus (note interleaving sutural teeth between plates) and $E$. hembeli (note interlocking teeth between plates, respectively). Sutural teeth in both of these species can be obliterated by corrosion. C: carina; CL: carinolateral (or carinolateralis); R: rostrum; RL: rostrolateral; S: scutum; T: tergum 


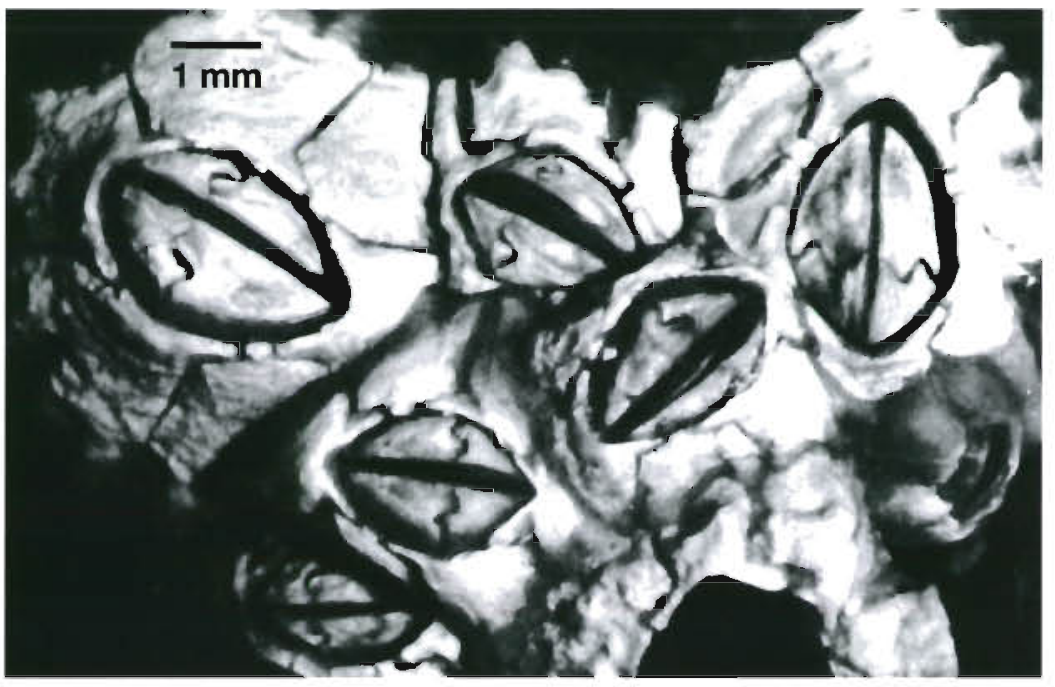

Fig. 2. Chthamalus proteus. Mature specimens from Pearl Harbor, settled on painted steel (collected by S.L.C.)

be possible to suggest from where this immigrant arrived in the islands. We therefore compared Hawaiian material with several other species, both by conventional morphology and by allozyme electrophoresis. Previous investigations of Chthamalus species have shown the value of allozyme comparisons, not only in separating subgenera and species but also in pointing out possible varietal differences (Dando et al. 1979, Hedgecock 1979, Dando \& Southward 1980, 1981, Miller et al. 1989).

The Hawaiian specimens were externally unlike typical Chthamalus species from the Pacific coast of America, such as C. fissus Darwin, 1854 of Southern and Central California and its southern allies, including C. panamensis Pilsbry, 1916. This suggested

a book on the marine fauna for Hawaii), in Pearl Harbor (by S.L.C. during a survey of the intertidal fauna there), and at various localities along the south coast of Oahu (by P.E.P.; Fig. 3). It has also been found on Kauai (Nawiliwili Harbor and Port Allen) and Maui (Kahului Harbor and Maalea Small Boat Harbor; R.D. pers. obs.).

Chthamalus is notorious for a lack of easy means of species identification. With a known identity, it would an origin from the western Pacific, since trends of faunal dispersal across the Pacific show a greater influence from the west than from the east (Zimmerman 1963, Newman \& Foster 1983, Newman 1986, Parin et al. 1997). However, one of us (A.J.S.) thought that the introduced Hawaiian Chthamalus resembled a tropical western Atlantic species that can be found in embayments; Chthamalus proteus Dando et Southward, 1980. Morphological comparisons were therefore made

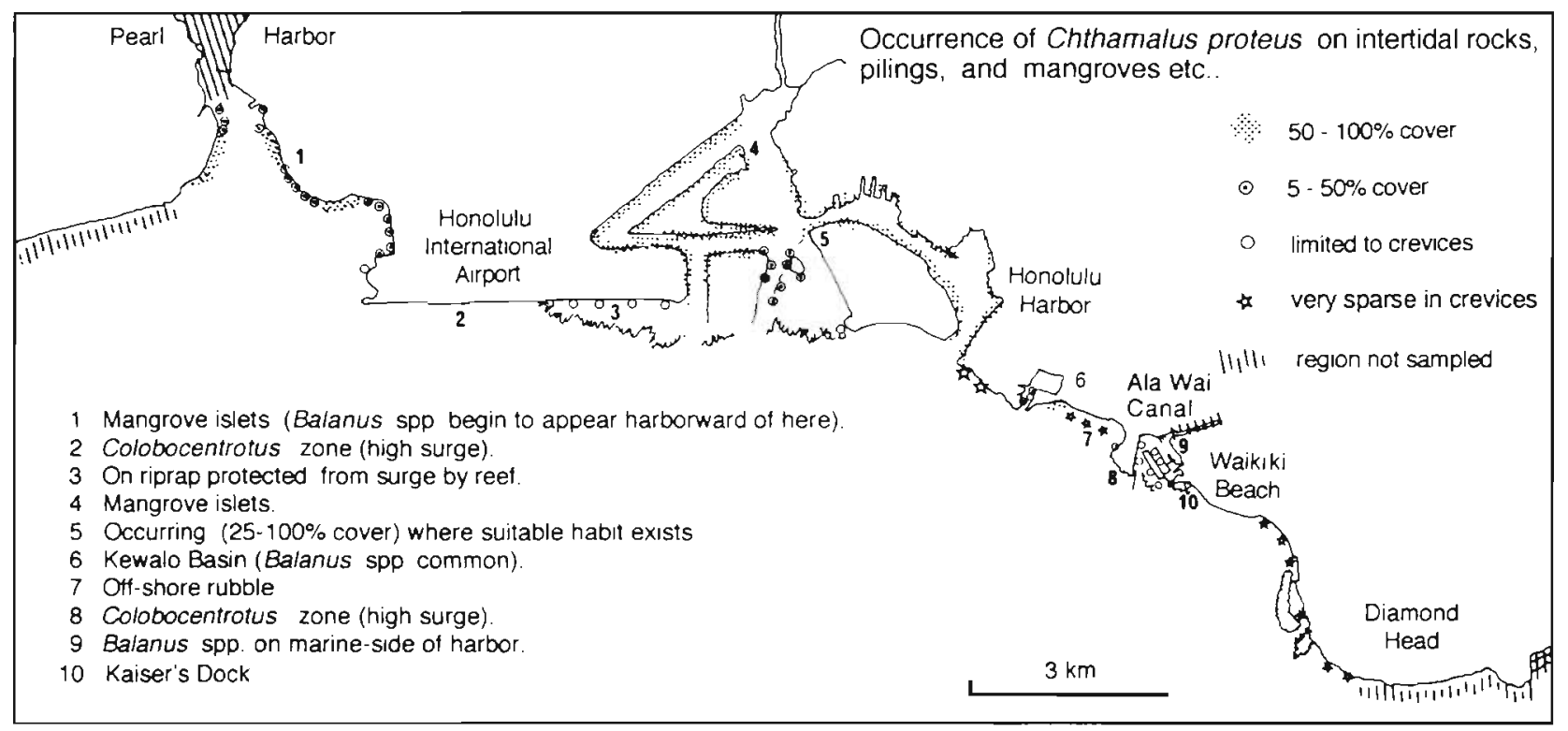

Fig. 3. Survey (by P.E.P.) of the occurrence and relative abundance of Chthamalus proteus along the south coast of Oahu, between Diamond Head and Pearl Harbor in 1996. Pearl Harbor and Kaneohe Bay were not sampled during this survey, but $C$. proteus is abundant in the latter (J.H. pers. obs.) as well as the former (S.L.C. pers. obs.). The Ala Wai Canal and the coastline east of Diamond Head were not included in this survey. In June 1996 C. proteus was not found in the Canal and the adjacent yacht basin, or on the old dock on Diamond Head at the foot of Coconut Street, or on the inshore barrier reef in Hanauma Bay (T.Y. \& W.A.N. pers. obs.) 
with Atlantic as well as Pacific material, and proteins of specimens from both oceans compared with those of the Hawaii specimens by gel electrophoresis

\section{MATERIAL AND METHODS}

Chthamalus challengeri Hoek, 1883 from Japan (collected by T.Y.) was used after storage at $-70^{\circ} \mathrm{C} ; \mathrm{C}$. fissus Darwin was collected on mussels from the Scripps pier (by W.A.N.), and used fresh; C. montagui Southward and C. stellatus (Poli, 1791) were collected at Wembury, near Plymouth, England (by A.J.S.), and carried alive to San Diego; frozen specimens of C. proteus, originally collected by the late Professor Dennis Crisp on the Louisiana coast of the Gulf of Mexico in 1986, were conveyed in liquid nitrogen from Menai Bridge, North Wales to Plymouth (by P.R.D.) and from there carried on dry ice to California (by A.J.S.). The first Hawaiian sample, sent fresh from Pearl Harbor (by S.L.C.), was delayed in transit and used only for morphology; the second, sent from Kaneohe Bay (by J.H.), was used for electrophoresis aíter storage at $-70^{\circ} \mathrm{C}$.

Cirri and mouth parts were dissected and mounted in glycerin jelly or polyvinyl-lactophenol for light microscopy (A.J.S. \& W.A.N.).

Electrophoresis was carried out (R.S.B.) on $0.8 \mathrm{~mm}$ thick vertical slab gels of $6 \%$ total acrylamide in a continuous Tris-boric acid-EDTA (0.1 M, pH 8.9) buffer system. Soft tissues from individual barnacles were dissected from the shell and macerated in approximately 10 volumes of homogenization buffer (electrophoresis buffer with $10 \%$ sucrose and $0.05 \%$ bromphenyl blue added) in a $0.5 \mathrm{ml}$ microcentrifuge tube using a fitted plastic pestle. Samples were then centrifuged at $10000 \times g$ for 2 min and 3 to $6 \mu$ lof the supernatant was loaded into the slots of each of 4 gels. Gels were run at $120 \mathrm{~V}$ for $4.0 \mathrm{~h}$ at $10^{\circ} \mathrm{C}$. Stains for $\mathrm{MDH}$ (malate dehydrogenase), PGM (phosphoglucomutase), GPI (glucose-phosphate isomerase) and MPI (mannose-phosphate isomerase) followed Harris \& Hopkinson (1976); GOT (glutamate-oxaloacetate transaminase $=$ aspartate aminotransferase) was assayed using a fluorescent stain and filter paper overlay as described in Burton \& Feldman (1981).

\section{RESULTS}

\section{Morphology}

Morphological comparison of the Hawailan specimens with the common barnacle of the northern Japanese coast, Chthamalus challengeri Hoek, showed they were not this species. However, it should be noted that the original description of $C$. challengeri is based on type material taken from the lifting screw of H.M.S. 'Challenger' after a sojourn in Japanese waters (Hoek 1883). The original description is incomplete by today's standards and there is thus some confusion about important cirral characters. Few of those who have redescribed $C$. challengeri have seen the type specimens. Pilsbry (1916) described much variation between samples, including a named subspecies $(C$. challengeri nipponensis), and he would seem to have been working on a mixture of species. But it is from Pilsbry that the idea grew that $C$. challengeri possessed bidenticulate setae with basal guards on the second cirri (Fig. 4, Table 1). This character was described by Pilsbry for a specimen from Matsushima, a lagoon-like environment on the north-east coast of Honshu. In the type material, and in other typical Japanese specimens we have seen, the second cirri carry finely bidenticulate setae without basal guards. This is in accord with the re-examination made by Nilsson-Cantell (1921), so that Pilsbry's contrasting specimen musi have belonged io anointer species on been taken in another locality.

The type of complex setae on the second cirri and the presence or absence of conical spines on the first cirri are indeed useful characters that help to separate groups of the species of Chthamalus (Fig. 4). Table 1 lists these characters, updating a similar table in Dando \& Southward (1980). Fig. 5 shows the complex setae of the distal segment of the outer ramus of cirrus II of a
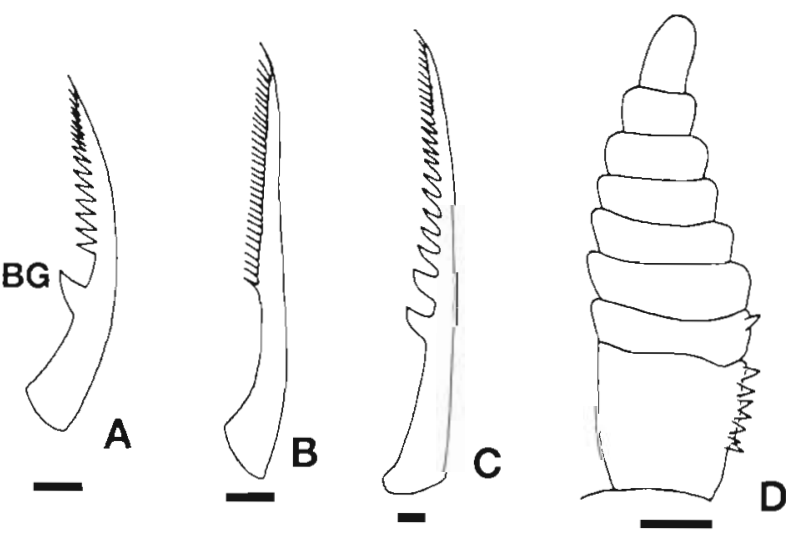

Fig. 4. Examples of the complex setae and conical spines of Chthamalus (cf. Table 1). (A) Bidenticulate seta with basal guards (BG); (B) finely bipectinate form of a seta without basal guards; and $(C)$ bidenticulate seta without basal guards, denticulations becoming coarser at the proximal end. For clarity, all setae are shown with only 1 row of setules, not 2 rows. (D) Anterior ramus of a cirrus I showing conical spines on the inside of the first 2 segments; all other setae omitted for clarity. Scale bars: $(A, B, C) 10 \mu m_{i}$ (D) $100 \mu \mathrm{m}$. Note that the division between denticulate and pectinate forms of the complex setae is subjective 
Table 1. Distinguishing characters of cirri I and II in Chtha. malus. Setae and spines are illustrated in Fig. 4

\begin{tabular}{|lcc|}
\hline Species & $\begin{array}{c}\text { Cirrus I } \\
\text { with conical } \\
\text { spines }\end{array}$ & $\begin{array}{c}\text { Cirrus II } \\
\text { bidenticulate setae } \\
\text { with basal guards }\end{array}$ \\
\hline $\begin{array}{l}\text { 'Challengeri' group } \\
\text { C. challengeri }\end{array}$ & No & No \\
C. dalli & No & No \\
C. montagui & No & No \\
C. antennatus & No & No \\
C. sinensis & No & No \\
'Fissus' group & & \\
C. anisopoma & No & Yes \\
C. fissus & No & Yes \\
C. fragilis & No & Yes \\
C. panamensis & No & Yes \\
C. proteus & No & Yes \\
'Stellatus' group & & No \\
C. angustitergum & Yes & No \\
C. bisinuatus & Yes & No \\
C. stellatus & Yes & \\
'Malayensis' group & & Yes \\
C. malayensis & Yes & Yes \\
C. dentatus & Yes & \\
aSpecimens not seen, data from Ren (1984) & \\
\hline & & \\
\hline & & \\
\hline
\end{tabular}

specimen of Chthamalus from Kaneohe Bay. Discernment of the fine details of such complex setae is not always easy. The fine pectinations of the complex setae of $C$. challengeri are particularly difficult to photograph using light microscopy.

From the first and second cirral characters alonethe presence of complex setae with basal guards on cirrus II (Fig. 5) and the absence of conical spines on the first cirri-it was clear that the Hawaiian Chthamalus was not $C$. challengeri. The west coast American species $C$. dalli Pilsbry, 1916, C. fissus, $C$. anisopoma Pilsbry, 1916 and C. panamensis were also ruled out, the first by cirral characters, and the others by differences in the opercular plates. In contrast, the Hawaiian specimens were very close to $C$. proteus in cirral characters as well as the opercular plates.

There remained the possibility that Chthamalus proteus was perhaps a representative of a more widespread group of Chthamalus species with similar cirral characters, and that there were as yet undiscovered members of this group in the western Pacific. The form of the complex setae, like other arthropod characters used by cirriped taxonomists, does not necessarily separate closely related species, but is good for generic and subgeneric separation (Table 1; Dando \& Southward 1980). This is not normally a problem in most parts of the world since apparently sympatric species with established morphological and biochemical differences usually belong to differing subgenera, as for example C. stellatus and C. montagui in Europe (South- ward 1976, Dando \& Southward 1980, 1981), C. fissus and $C$. dalli in California (Miller et al. 1989), and $C$. proteus and $C$. angustitergum Pilsbry, 1916 in the Caribbean (Dando \& Southward 1980)

Examination of archived material from the western Pacific and data from a recent publication on chthamalids of the area (Ren 1984) failed to reveal any species with setal characters comparable to Chthamalus proteus. C. malayensis Pilsbry, 1916, which has complex setae with basal guards, is separable by the presence of conical spines on the base of the first cirri. Chthamalus sinensis Ren, 1984 from China, resembles C. antennatus Darwin, 1854 from Australia and fits better with the challengeri group of species (Table 1). However, the possibility remained that there was an undetected western Pacific species close to $C$. proteus that might have been the source of the Hawaiian material. It was therefore essential to check relationships at the protein level.

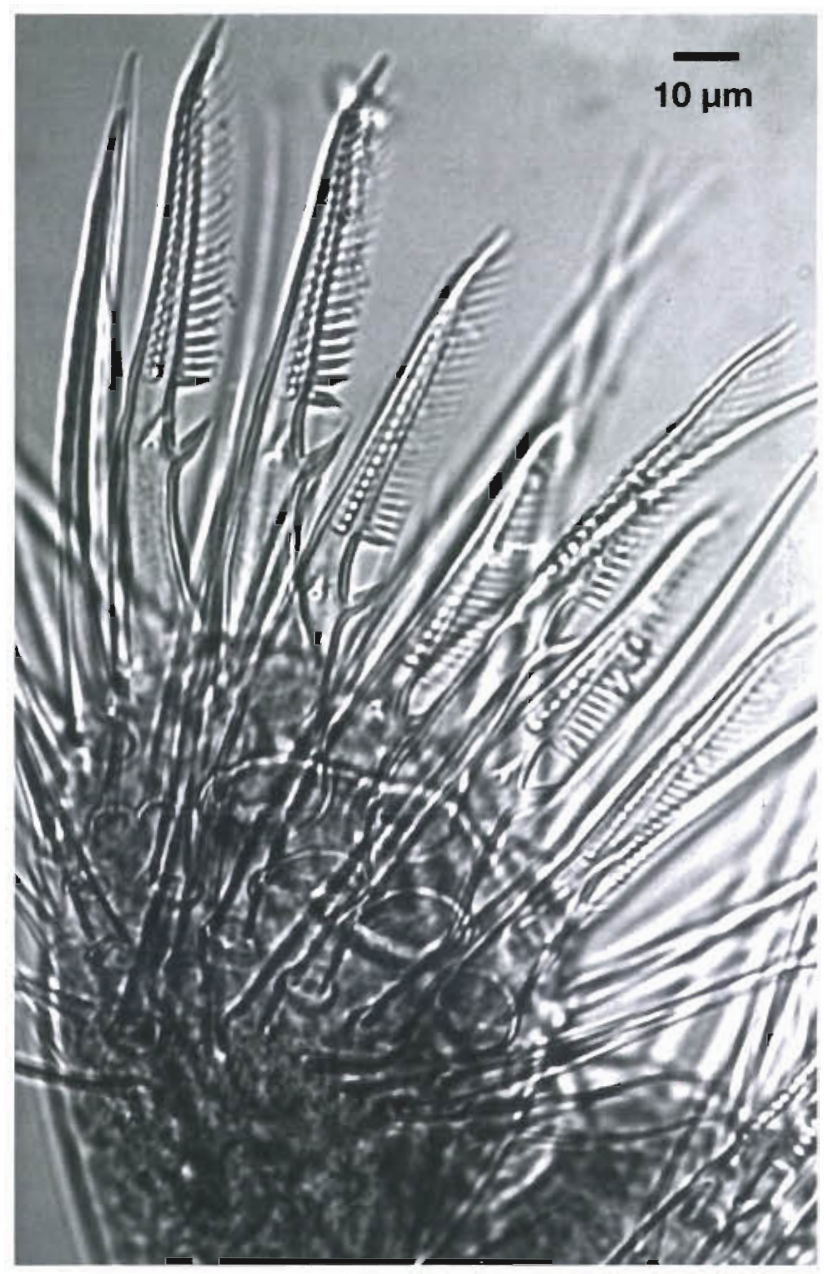

Fig. 5. Chthamalus proteus. Distal segment of the outer ramus of cirrus Il from a specimen collected in Kaneohe Bay showing the bidenticulate spines with basal guards 
Table 2. Electrophoretic mobility ( $\mathrm{mm}$ ) of allozymes from various Chthamalus taxa. Multiple numbers indicates genetic polymorphism. $\mathrm{n}=$ sample size, nd: no activity detected

\begin{tabular}{|c|c|c|c|c|c|c|c|c|}
\hline Sample & $\mathrm{n}$ & GPI & GOT 1 & GOT2 & $\begin{array}{c}\text { Locus } \\
\text { MPI }\end{array}$ & MDH1 & MDH2 & PGM1 \\
\hline Chthamalus sp. (Hawaii) & 10 & 35 & 45 & 17,22 & 25 & 44 & 33 & 60 \\
\hline C. proteus (Louisiana) & 11 & 35 & 45 & 22 & 25 & 44,48 & 33 & 60 \\
\hline C. challengeri (Japan) & 3 & 40 & 45 & 22 & 27 & 44,48 & 33,35 & 70 \\
\hline C. fissus (California) & 4 & 20.25 & 45 & 31 & 27 & 39,44 & 33 & 45 \\
\hline C. montagui (Plymouth) & 5 & 30,35 & 49 & 24 & 20 & 44 & 30,35 & nd \\
\hline C. stellatus (Plymouth) & 1 & 40 & 49 & 24 & 22 & 44 & 27 & nd \\
\hline
\end{tabular}

\section{Enzyme electrophoresis}

The electrophoretic mobilities of 8 proteins resolved from several Chthamalus taxa are presented in Table 2. Despite small sample sizes (1 to 11 individuals per taxon) and the relatively few loci scored, some general patterns are clear. In particular, specimens of Chthamalus sp. from Hawaii were readily distinguished from Chthamalus samples taken from either side of the Pacific Basiñ. The C. challengeri fiùn Japan difiered from the Hawaiian specimens at 3 of the 7 loci while C. fissus from California differed at 4 of 7 loci. In contrast, the Hawaiian specimens share alleles with $C$. proteus from the Louisiana coast of the Gulf of Mexico at every one of the 7 loci for which we obtained data. Although such allozyme data cannot be taken as definitive proof of the identity of the 2 samples, it is completely consistent with the morphological data and adds independent support for the identification.

\section{DISCUSSION}

From the 2 sets of data, morphology and allozymes, it is virtually certain that the Hawaiian introduction is Chthamalus proteus. Even if this east coast species had somehow become a resident, undetected, on the Pacific Coast of the Americas, as may have happened with Balanus eburneus, the evidence is against natural dispersal of American faunistic elements westward across the ocean (Newman \& Foster 1976, Newman 1986). Carlton (1987) has discussed problems of transPacific transfer of marine organisms; interestingly enough, his data show much greater frequency of invasion of Hawaii from the west and southwest compared with the eastern side of the Pacific. Therefore it is most likely that $C$. proteus reached Hawaii by remote dispersal, probably by human agency. The date of introduction was after 1973 and it could have been as recently as 1994 or 1995 (Matsuda 1973, Evans et al. 1974, Coles et al. 1997). However, considering the present distribution of $C$. proteus in the islands and the usual lag time between an introduction and notable abundance, it was possibly earlier, but at first more localised.

The original introduction of Chthamalus proteus was probably into Pearl or Honolulu Harbor. The question is how? Most species of Chthamalus do not occur below low tide and they are not typical foulers of ship's hulls. Indeed, the recently settled stages of C. montagui have been shown to need daily exposure to air io survive and grow (Burrows $1 \bar{y} \overline{8} \bar{l}$ ), though aduits may live for over a year under continuous submersion (Barnes 1956, as C. stellatus). C. proteus can sometimes be found in what might be regarded as fouling situations, i.e. the rotating steel intake screens of the Power Station at Port of Spain, Trinidad (A.J.S. pers. obs.) and pilings in several other Caribbean harbors (Southward 1975, recorded as C. bisinuatus; Dando \& Southward 1980), but these are places where the barnacles are not continuously submerged. Thus any shipborne carriage would have been expected to be in association with mooring devices and fenders, rather than the bottom of a ship. However, the recent discovery of $C$. proteus above the waterline on hulls of commercial vessels, including barges, passenger craft and research ships, in Hawaiian waters (P.E.P. pers. obs.) is very surprising and considerably extends the possibilities for introduction. In any event the ship or ships introducing $C$. proteus must have remained for some time in harbor after arrival in Hawaii. A reasonably fast transit between the port of origin and the port of first release of larvae, including passage through the Panama Canal would also be required. Although most Chthamalus species can resist desiccation (Monterosso 1930), and also temporary immersion in diluted seawater, by closing of the opercular valves (Foster 1970 , pers, obs.), we find they will survive more than a week or two out of the sea only if they are screened from direct sunlight and the air is humid. Rapid transit and subsequent long stay is suggestive of defence or tourist activities rather than commercial shipping. However, commercial vessels from, say, the Gulf of Mexico, that then remain in Hawail for local journeys, e.g. ferries, 
oil-rig vessels, or bulk-transport barges, cannot be discounted.

Another possibility is carriage of nauplii in ballast water. Carlton \& Geller (1993) have reported 5 taxa of cirripede nauplii arriving in Oregon in ballast water tanks of ships from Japan. This possibility is less likely than transport of adults, since a dense settlement is needed to establish a breeding population of such obligate cross-fertilizing sessile animals.

A supplementary question is why did this introduction not occur earlier, for example between 1928 and the 1940 s when Balanus eburneus was apparently introduced from eastern America, probably via the Panama Canal (Matsui et al. 1964)? It should be noted that $B$. eburneus is common along the east coast of USA, and is believed to have been introduced to Europe about the turn of the century. It has been reported in Japan by Utinomi (1966), and on the west coast of America (Manzanillo and Mazatlan, Mexico; Balboa, Panama Bay) by Henry \& McLaughlin (1975). Furthermore, $B$. amphitrite, suspected of arriving in southern California in the early 1920s (Zullo et al. 1972), was first reported from Hawaii by Broch (1922) in collections made in 1914 .

A parallel might be drawn with the invasion of Europe by the barnacle Elminius modestus Darwin from New Zealand during World War II (Bishop 1947. Bishop et al. 1957, Fischer-Piette 1965). A substantial part of the goods and passenger traffic between England and New Zealand just before the war was carried by fast ships with short turn round times transporting perishable items such as meat, dairy products and fruit. When the war began in September 1939 these ships were held in English south coast harbors while the convoy system was inaugurated, and it is believed that this gave the fouling barnacles the opportunity to release large numbers of larvae into the harbors, enough to establish a viable breeding population. Carlton (1987) has noted changes in Pacific Ocean traffic since World War II. The authors would be interested to learn of any changes to ship traffic between the tropical western Atlantic and Hawaii since 1973 that might have produced an opportunity for the invasion of Hawaii by Chthamalus proteus.

A final question is what of the future? Other introductions and invasions elsewhere have led to alarm about harmful effects on existing ecosystems. In the present case it is clear that Chthamalus proteus is now well-established in the Hawaiian Islands and likely to be a permanent feature of the upper mid-littoral and splash zone in harbors and bays. It has established itself by exploiting a largely vacant niche, and it increases the complexity of the food web, with the possibility that it might stabilize the harbor ecosystem.
A prognosis can be made by comparison with the situation in the Caribbean. In wave-beaten situations there, Chthamalus proteus is replaced by $C$. angustitergum. Therefore we do not expect that $C$. proteus will become dominant on the outer coastal rocks, where Nesochthamalus intertextus is found. $N$. intertextus is commoner in cryptic situations or where the rocks remain damp, and is sometimes accompanied by the less numerous Euraphia hembeli (Conrad, 1837), which can grow to a larger size than any other chthamaline (see Fig. 1; Foster \& Newman 1987). These 2 chthamaloids are found throughout most of the tropical western Pacific as well as in Hawaii. While they occasionally found in small groups, and Pilsbry (1928) shows a photograph of a patch of contiguous individuals of $N$. intertextus from Kahuku Point, Oahu, they are not known to form a typical, dense intertidal barnacle zone. In this they differ from C. proteus.

Although this introduction may be relatively benign, its occurrence shows there is a need to step up monitoring programs to prevent, rather than simply observe, potentially harmful introductions to the marine fauna of the Hawaiian Islands

Note added in proof: There are recent reports of Chthamalus proteus at Midway Island (R. DeFelice) and in Apra Harbor, Guam, and possibly Ponape (Y Hisatsume per $T$ Yamaguchi $\&$ G. Paulay). Thus the suggested path of immigration of the species to the Pacific may need to be revised.

Acknowledgements. We thank Arnold Ross for comments on the manuscript. W.A.N. and T.Y. are indebted to Flora Olsen for logistic support during a visit to Oahu in June 1996

\section{LITERATURE CITED}

Barnes $H$ (1956) The growth rate of Chthamalus stellatus (Poli). J Mar Biol Assoc UK 35:355-361

Bishop MWH (1947) Establishment of an immigrant barnacle in British coastal waters. Nature (Lond) 159:501

Bishop MWH, Crisp DJ, Fischer-Piette E, Prenant M (1957) Sur l'écologie des Cirripèdes de la côte atlantique française. Bull Inst Océanogr V(1099):1-12

Broch H (1922) Papers from Dr. Th. Mortensen's Pacific Expedition 1914-1916. X. Studies on Pacific cirripeds. Vidensk Medd Dan Naturhist Foren 73:214-358

Burrows MT (1988) The comparative biology of Chthamalus stellatus (Poli) and Chthamalus montagui Southward. PhD thesis, University of Manchester

Burton RS, Feldman WM (1981) Population genetics of Tigriopus californicus: II. Differentiation among neighboring populations. Evolution 35:1192-1205

Carlton JT (1987) Patterns of transoceanic marine biological invasions in the Pacific Ocean. Bull Mar Sci 4:452-465

Carlton JT, Geller JB (1993) Ecological roulette: the global transport of non indigenous marine organisms. Sciences (NY) 26:78-82

Coles SL, DeFelice RC, Eldredge LG, Carlton JT, Pyle RL, Suzumoto A (1997) Biodiversity of marine communities in 
Pearl Harbour, Oahu, Hawaii with observations on introduced exotic species. Department of Defence Legacy Project No. 106, US Navy. Bishop Museum Tech Rep No. 10 , Bishop Museum, Honolulu

Dando PR, Southward AJ (1980) A new species of Chthamalus (Crustacea: Cirripedia) characterized by enzyme electrophoresis and shell morphology: with a revision of other species of Chthamalus from the western shores of the Atlantic Ocean. J Mar Biol Assoc UK 60:787-831

Dando PR. Southward AJ (1981) Evidence of Atlantic and Mediterranean forms of Chthamalus montagui (Crustacea, Cirripedia) in the Western Mediterranean. Mar Biol Lett $2: 239-248$

Dando PR, Southward AJ, Crisp DJ (1979) Enzyme variation in Chthamalus stellatus and Chthamalus montagui (Crustacea: Cirripedia): evidence for the presence of $C$. montagui in the Adriatic. J Mar Biol Assoc UK 59:307-320

Edmondson $\mathrm{CH}$ (1946) Reef and shore fauna of Hawaii. Bishop Museum, Honolulu

Ekman S (1953) Zoogeography of the sea. Sidgwick \& Jackson, London

Evans ECl, Buske NL, Grovhoug JG, Guinther EB, Jokiel PL, Kam TO, Kay EA, Peeling TJ, Smith SV (1974) Pearl Harbour biological survey - final report. Rep no NUC TN 1128. Naval Undersea Center (NUC), San Diego

Fischer-Piette E (1965) Suite de l'expansion sur la côte atlantique française du Cirripède austral Elminius modestus Darwin. Buil Mus Natn Hist Nat 2, 37:466-468

Foster BA (1970) Responses and acclimation to salinity in the adults of some balanomorph barnacles. Phil Trans R Soc Lond B 256:377-400

Foster BA, Newman WA (1987) Chthamalid barnacles of Easter Island; peripheral Pacific isolation of Notochthamalinae subfam. nov. and hembeli-group of Euraphinae (Cirrupedia: Chthamaloidea). Bull Mar Sci 41:322-336

Harding JP (1962) Darwin's type specimens of varieties of Balanus amphitrite. Bull Brit Mus (Nat Hist) 9:273-296

Harris H, Hopkinson DA (1976) Handbook of enzyme electrophoresis in human genetics. North-Holland, Amsterdam

Hedgecock D (1979) Biochemical genetic variation and evidence of speciation in Chthamalus barnacles of the tropical eastern Pacific Ocean. Mar Biol 54:207-214

Henry DP, McLaughlin PA (1975) The barnacles of the Balanus amphitrite complex (Cirripedia, Thoracica). Zool Verhand (Leiden) 141:1-254

Hoek PPC (1883) Report on the Cirripedia collected by H.M.S. Challenger during the years 1873 to 1876 . Reports of the Scientific Results of the exploring voyage of H.M.S. Challenger. Zoology 8:1-165

MacArthur RH, Wilson EO (1967) The theory of island biogeography. Princeton University Press, Princeton, NJ

Matsuda C (1973) A shoreline survey of free-living intertidal barnacles (Class Crustacea; Subclass Cirripedia; Order Thoracica) on the island of Oahu, Hawaii. MSc thesis, University of Hawaii, Honolulu

Matsui T. Newman WA, Shane G (1964) On Balanus eburneus

Editorial responsibulity: Otto Kinne (Editor),

Oldendort/Luhe, Germany
Gould (Cirripedia, Thoracica) in Hawaii. Crustaceana 7 $141-145$

Miller KM, Blower SM, Hedgecock D, Roughgarden J (1989) A comparison of the larval and adult stages of Chthamalus dalli and Chthamalus fissus (Cirripedia: Thoracica). $\mathrm{J}$ Crustac Biol 9:242-256

Monterosso B (1930) Studi Cirripedologici, VI: reactions of C. stellatus under experimental conditions. Rend Accad Lincei 9:501-505

Newman WA (1960) On the paucity of intertidal barnacles in the tropical Western Pacific. Veliger 2:89-94

Newman WA (1986) Origin of the Hawaiian marine fauna: dispersal and vicariance as indicated by barnacles and other organisms. Crustac Issues 4:21-49

Newman WA, Foster BA (1983) The Rapanuian faunal district (Easter and Sala y Gomez): in search of ancient archipelagos. Bull Mar Sci 33:633-644

Newman WA, Ross A (1976) Revision of the balanomorph barnacles; including a catalog of the species. Mem San Diego Soc Nat Hist 9:1-108

Nilsson-Cantell CA (1921) Cirripeden-Studien. Zur Kenntnis der Biologie, Anatomie und Systematik dieser Gruppe. Zool Bidr Uppsala 7:75-395

Parin NV, Mironov AN, Nesis KN (1997) Biology of the Nazca and Sala y Gomez submarine ridges, an outpost of the Indo-West Pacific fauna in the eastern Pacific Ocean: composition and distribution of the fauna, its communities and history. Adv Mar Biol 32:145-242

Pilsbry HA (1916) The sessile barnacles (Cirripedia) contained in the collections of the US National Museumi including a monograph of the American species. Bull US Nat Mus 93:1-366

Pilsbry HA (1928) Littoral barnacles of the Hawaiian Islands and Japan. Proc Acad Nat Sci Philadelphia 79:305-317

Ren X (1984) Studies on Chinese Cirripedia (Crustacea) III. Family Chthamalidae. Stud Mar Sinica 22:145-163

Southward AJ (1975) Intertidal and shallow water Cirripedia of the Caribbean. Stud Fauna Curaçao Other Caribb Isl $46: 1-53$

Southward AJ (1976) On the taxonomic status and distribution of Chthamalus stellatus (Cirripedia) in the north-east Atlantic region: with a key to the common intertidal barnacles of Britain. J Mar Biol Assoc UK 56:1007-1028

Utinomi $\mathrm{H}(1960)$ On the world-wide dispersal of a Hawaiian barnacle. Balanus amphitrite hawaiiensis Broch. Pac Sci $14: 43-50$

Utinomi. H (1966) Recent immigration of two foreign barnacles into Japanese waters. Proc Jpn Soc Syst Zool 2:36-39

Utinomi $H$ (1.967) Comments on some new and already known cirripeds with emended taxa, with special reference to the parietal structure. Publ Seto Mar Biol Lab 15:199-237

Zimmerman EC (1963) Pacific Basin biogeography: a summary discussion. In: Gressitt JL (ed) Pacific Basin biogeography. BP Bishop Museum, Honolulu, p 477-481

Zullo VA, Beach DB, Carlton JT (1972) New barnacle records (Cirripedia, Thoracica). Proc California Acad Sci (Ser 4) $39(6): 65-74$

Submitted: January 28, 1998; Accepted: March 5, 1998 Proofs reccived from author(s): April 15, 1998 